\title{
Vitamin C, Anti-Infective Immunity and the Issue of Decreased Vitamin C Levels in Children
}

\author{
Jan Boženský ${ }^{1}$, František Kopřiva ${ }^{2}$, Lucie Kotlářová ${ }^{3 *}$, Pavel Kostiuk ${ }^{4}$, Zdeněk Procházka ${ }^{4}$ and \\ Jiří Slíva ${ }^{5}$ \\ ${ }^{1}$ Department of Pediatrics, Agel Hospital, Ostrava-Vítkovice, Czech Republic
}

${ }^{2}$ Department of Pediatrics, Olomouc University Hospital, Czech Republic

${ }^{3}$ InPharm Clinic, Jesenice u Prahy, Czech Republic

${ }^{4}$ Edukafarm, Prague, Czech Republic

${ }^{5}$ Institute of Pharmacology, Third Faculty of Medicine, Charles University, Czech Republic

*Corresponding author: Lucie Kotlářová, InPharm Clinic, Jesenice u Prahy, Czech republic. E-mail: kotlarova@inpharmclinic.cz

\section{ARTICLE INFO}

Received: 幽 April 14, 2021

Published: 豐 April 22, 2021

Citation: Jan Boženský, František Kopřiva, Lucie Kotlářová, Pavel Kostiuk, Zdeněk Procházka, Jiř́i Slíva. Vitamin C, AntiInfective Immunity and the Issue of Decreased Vitamin C Levels in Children. Biomed J Sci \& Tech Res 35(2)-2021. BJSTR. MS.ID.005679.

Keywords: Vitamin C; Ascorbic Acid; Anti-Infectious Immunity; Vitamin C Deficiency; Screening for Vitamin C Levels in the Urine; Test Strips to Determine Vitamin C Levels in the Urine

\section{ABSTRACT}

Aim of Study: To determine the incidence of decreased vitamin C levels in children hospitalized in the pediatric departments of two hospitals in the Ostrava and Olomouc regions, Czech Republic.

Methods: Preliminary assessment of tissue vitamin C saturation using test strips to ascertain the levels of ascorbic acid in the urine. The non-invasive technique is based on the reaction of a chelating agent with a polyvalent metal ion. Test strip are dipped in subjects' urine and results are read by matching any color change on the strip with the provided color chart.

Results: In the Department of Pediatrics of Ostrava-Vítkovice Hospital (Czech Republic), study investigators identified, $23 \%$ children with the most severe level of vitamin $\mathrm{C}$ deficiency in the urine $(1 \mathrm{mg} / \mathrm{dL})$, with the levels of vitamin $\mathrm{C}$ deficiency of $10 \mathrm{mg} / \mathrm{dL}, 20 \mathrm{mg} / \mathrm{dL}$ and $50 \mathrm{mg} / \mathrm{dL}$ diagnosed in $41 \%, 11 \%$, and $14 \%$ of children, respectively whereas full tissue vitamin C saturation ( $100 \mathrm{mg} / \mathrm{dL})$ was found in only $11 \%$ of children. Thus, overall, $75 \%$ of children had appreciable vitamin C deficiency with only $25 \%$ of children showing relatively adequate tissue vitamin $\mathrm{C}$ saturation. On admission and during hospitalization, 59\% of pediatric patients were on pharmacotherapy; of these, $18 \%$ were diagnosed with severe vitamin C deficiency at a level of $1 \mathrm{mg} / \mathrm{dL}$, with the levels of vitamin C deficiency of $10 \mathrm{mg} / \mathrm{mL}, 20 \mathrm{mg} / \mathrm{mL}$ and $50 \mathrm{mg} / \mathrm{mL}$ determined in $43 \%, 9 \%$ and $16 \%$ of children, respectively. Adequate vitamin C saturation was found in only $14 \%$ of the children. The same tests performed in the Department of Pediatrics of Olomouc University Hospital revealed decreased vitamin C levels in 98\% of hospitalized pediatric patients.

Conclusion: Our study showed decreased vitamin C levels in the overwhelming majority of children hospitalized in the aforementioned medical centers. Given the crucial importance of vitamin $\mathrm{C}$ for the immune and other body systems, our results highlight the need for determining, at least tentatively, (e.g., using urine test strips) vitamin $\mathrm{C}$ saturation and, if needed, to provide adequate vitamin $\mathrm{C}$ supplementation as a prerequisite for achieving good health in the pediatric population. 


\section{INTRODUCTION}

\section{Vitamin $C$ and anti-infective immunity}

Vitamin C is a substance essential for humans at all stages of their growth and development. It is necessary for physiological development during ontogenesis, as well as for the proper functioning of all body systems in childhood, adolescence and adulthood [1]. The importance of adequate vitamin C supply for the immune system to work properly has long been empirically known. Individuals with inadequate vitamin C intake are not only susceptible to frequent infections, but the course of infectious diseases is more serious, and there is an increased risk of developing a variety of chronic conditions [2]. A critical role in antibacterial immunity is played by the barrier function, primarily that of the mucous membrane. Sufficient vitamin C levels are also critical for adequate functioning of all types of leukocytes (including their migration, ability to destroy pathogens and apoptosis of exhausted cells). Under normal conditions, vitamin $\mathrm{C}$ levels in these cells are more than a hundred-fold higher compared with those in plasma. Antimicrobial immunity involves phagocyte migration to the focus of the infection and, once phagocytosis of microbes has occurred, apoptosis of exhausted cells. The local antigen-presenting cells transfer the information about the pathogen to regional memory $\mathrm{T}$ cells, which exert cytotoxic action on bacteria followed by activation of B cells transforming to plasma cells to produce antibodies. Other types of cells involved in antibacterial immunity include Th1 cells which activate bacteria-killing macrophages, and Th2 cells, which stimulate B cells to produce antibodies. Proper functioning of these cells requires sufficient levels of vitamin C [2].

Likewise, efficient antiviral immunity requires adequate vitamin $\mathrm{C}$ levels., as does the important role played by the barrier function. The cornerstone of innate antiviral immunity is interferon (type I IFN), which most cells begin to produce upon viral invasion. An important component of non-specific antiviral immunity is NK (natural killer) cells. Phagocytosis of viruses is a major function performed primarily by macrophages. An efficient antiviral tool in this respect are antibodies produced by B cells. As to cell type-specific immunity, the most important players are cytotoxic CD8+ T cells. For all these components of antiviral immunity to work properly, sufficient supply of vitamin C is perquisite [2]. Given the significant effect of vitamin $\mathrm{C}$ on the immune system, its deficiency results in increased susceptibility to infectious diseases, which worsens the deficiency due to increased vitamin $\mathrm{C}$ consumption. As shown by various studies, patients with acute respiratory conditions, such as bronchopneumonia, often develop vitamin C deficiency [3]. Vitamin C supplementation in patients with respiratory tract infections will eliminate the deficiency and help improve the clinical prognosis [4]. Vitamin C deficiency, which frequently precedes the development of infectious diseases, further deteriorates during the course of the disease per se because of the increased vitamin $C$ consumption due to more intensive metabolism in the presence of inflammation.
This is also why the demand for vitamin $\mathrm{C}$ supplementation as part of management of infectious diseases is substantially higher than preventive doses. For example, several studies have shown that vitamin $C$ reduced the viral load in cells infected by Epstein-Barr virus (EBV) [5] or cytomegalovirus (CMV) [6].

Vitamin C significantly enhances chemotaxis and the phagocytic potential of neutrophils, i.e., oxidative destruction of pathogens in those cells while promoting lymphocyte proliferation and functioning $[7,8]$. Vitamin $\mathrm{C}$ deficiency results - when the body is exposed to the action of a virus - in high viral titers in the lungs and a decrease in the levels of the cytokines with antiviral action, particularly interferons alpha and beta $(\operatorname{IFN}-\alpha / \beta)$ [9]. Moreover, vitamin $\mathrm{C}$ deficiency is associated with increased production of anti-inflammatory cytokines such as tumor-necrosis factor (TNF) and interleukin-1 (IL-1) in the lungs. Once vitamin C deficiency has been eliminated, these detrimental processes cease. Studies have shown that vitamin $\mathrm{C}$ deficiency results in the formation of inflammatory lesions in the lungs when exposed to a viral infection (e.g., influenza), [10] whereas vitamin $\mathrm{C}$ supplementation has a beneficial effect on the health status of lungs in individuals with viral pneumonia [11]. The antiviral action of ascorbate has been documented with a host of viruses such as respiratory syncytial virus (RSV) [12-14].

\section{Decreased vitamin $\mathrm{C}$ levels and options for their detection and vitamin $\mathrm{C}$ supplementation}

\section{Worldwide Incidence of Decreased Vitamin C Levels}

Normal serum vitamin C levels are commonly defined as values above 28 micromoles/L ( $\mu \mathrm{mol} / \mathrm{L})$ with concentrations between 11 and $28 \mu \mathrm{mol} / \mathrm{L}$ considered hypovitaminosis (suboptimal levels); levels lower than $11 \mu \mathrm{mol} / \mathrm{L}$ are referred to as vitamin $\mathrm{C}$ deficiency. Given the above, values below $28 \mu \mathrm{mol} / \mathrm{l}$ are considered decreased vitamin C levels [15]. There is a general notion that low vitamin $\mathrm{C}$ levels in developed countries are a rare occurrence; regrettably, this is a common misconception. The incidence of decreased tissue vitamin $\mathrm{C}$ saturation is certainly not confined to developing regions, such that it affects, for example, $70 \%$ of the Ugandan population [16]. Quite surprisingly, vitamin C deficiency is frequently encountered in industrialized nations despite the general awareness and promotion of a healthy diet and the wide availability of vitamin C-containing foods and dietary supplements. Surveys have reported insufficient vitamin C intake in an approximately $20 \%$ of the European population [17]. The third Glasgow MONICA population survey documented vitamin C deficiency in $14 \%$ of women and 26\% men in Scotland [18]. A Canadian survey reported decreased vitamin $\mathrm{C}$ levels in almost half of the population, a finding correlating with higher rates of inflammatory diseases [15]. The prevalence of decreased vitamin C levels across Europe has been estimated at 17 and $33 \%$ by various studies [19]. 
The surprisingly high prevalence of decreased vitamin C levels even in developed countries is supported by a survey conducted in the USA and showing decreased (suboptimal) vitamin C levels in about one in five of those surveyed and severe vitamin $\mathrm{C}$ deficiency in $10 \%$ of the general population, with the implication being that about one in three Americans suffer from vitamin $\mathrm{C}$ deficiency. The aforementioned survey again confirmed a correlation between vitamin C deficiency and increased levels of inflammatory markers and other risk factors such as overweight, obesity and metabolic syndrome. As an important observation emerging from the survey, its authors suggest that the cause of decreased tissue saturation with vitamin $C$ is not only due to lower dietary intake but, also, diseases involving oxidative stress associated with increased utilization of ascorbate thus causing a decrease in systemic vitamin $\mathrm{C}$ levels [20]. Although the rates of decreased plasma vitamin C levels in children in developed regions of the world seem to be lower compared with adults, studies show that a limited intake of this vitamin (e.g., in underprivileged individuals) is associated with increased rates of vitamin C deficiency. This is exemplified by the pediatric population in Mexico where suboptimal vitamin $\mathrm{C}$ levels and deficiency were reported in $38 \%$ and $23 \%$ of children, respectively; hence, decreased vitamin $\mathrm{C}$ levels are present in over $60 \%$ of the children assessed. And again, a correlation was observed between decreased vitamin $\mathrm{C}$ levels and the incidence of overweight and obesity [21,22].

Case reports published in the USA suggest that severe vitamin C deficiency with symptoms of scurvy is not a rare occurrence even in children. Vitamin C deficiency is found most often in children with chronic conditions such as food allergies, malabsorption, renal failure, neurologic and psychiatric (e.g., autism spectrum) disorders or cancers. The cause of the deficiency may be, in some social strata, inadequate intake of vitamin C-rich foods due to excessively permissive education, religious habits, or even incorrectly defined diet composition. Factors potentially contributing to vitamin C (and, hence, its deficiency) may include use of some classes of drugs such as barbiturates [23,24]. The main factor determining tissue saturation with vitamin $\mathrm{C}$ is its oral intake, whether that be from the diet itself or from use of dietary supplements. As shown by earlier surveys, individuals of higher social standing who take dietary supplements containing vitamin $\mathrm{C}$ have a substantially lower risk of developing vitamin $\mathrm{C}$ deficiency. Vitamin $\mathrm{C}$ content in one's diet is determined by its composition and processing; thermal processing (e. g. cooking) is known to destroy vitamins. Tissue vitamin $\mathrm{C}$ saturation is further affected by environmental factors such as climate, season of the year, and place of residence. Pollution is another important factor which increases oxidative stress and, hence, the need for vitamin $\mathrm{C}$ supplementation. Other factors include demographic variables such as age and sex, plus socioeconomic factors such as social standing, education level, lack of access to vitamin C-rich foods and others. In addition, vitamin $\mathrm{C}$ levels are impacted by concurrent diseases, primarily chronic conditions associated with inflammation (e.g., infection), which as a consequence, precipitate the development of oxidative stress and increased vitamin C utilization [25,26].

\section{Preliminary Evaluation of Vitamin C Deficiency}

Since clinical signs of oxidative stress do not manifest themselves until the deficiency has become severe, it is appropriate to utilize methods which will detect vitamin C deficiency earlier. Identifying at-risk individuals, such as children treated on an out-patient basis or hospitalized, will help determine the extent of vitamin C supplementation necessary. One option to ascertain serum vitamin $\mathrm{C}$ levels is to use liquid chromatography, but this and other currently available techniques are relatively accurate, they are costly, time-consuming and require well trained staff and appropriately equipped centers. A technique deemed suitable for preliminary assessment of tissue vitamin $C$ saturation ascertains vitamin $\mathrm{C}$ levels in the urine; it is based on the reaction of a chelating agent with a polyvalent metal ion to form a chelate complex. As the dipstick test strip changes color, it is matched to the corresponding color on the provided color chart. The results offer preliminary information about any level of vitamin $\mathrm{C}$ deficiency. The values measured in the urine correlate with the plasma vitamin C levels and, by association, its tissue saturation [27].

\section{Options in Oral Supplementation}

In healthy children with normal vitamin $\mathrm{C}$ saturation, the recommended preventive oral doses are as follows: up to age 4 months, $50 \mathrm{mg}$; between 4 and 12 months, $55 \mathrm{mg}$; between 1 and 4 years, $60 \mathrm{mg}$, 4-7 years, $70 \mathrm{mg}$; 7-10 years, $80 \mathrm{mg}$; $10-13$ years, $90 \mathrm{mg}$, from 13 years upward and in adults, $100 \mathrm{mg}$; in pregnant women, $110 \mathrm{mg}$; and in breastfeeding women, 150 mg. In adolescence, in situations involving mental, emotional or physical stress, failure to thrive and loss of appetite, during the healing or recovery process, in inflammatory conditions associated with oxidative stress, in smoking (whether active or secondhand), in infectious diseases, in anemia and when taking some medications (e.g., oral contraceptives, corticoids, salicylates), the demand for vitamin $\mathrm{C}$ is appreciably increased. An optimal strategy is continuous monitoring of vitamin $\mathrm{C}$ saturation using the aforementioned test strips. In newborns and younger toddlers, the main source of vitamin $\mathrm{C}$ is breast milk, and in non-breastfed children, it is infant formula fortified with vitamin C. From months 6 onward, the principal source is raw (unprocessed) vegetables and fruits. However, as the vitamin C content in these sources is variable (due to storage conditions and processing), ensuring adequate vitamin $\mathrm{C}$ intake depends on dietary supplement use.

The issue with common oral dosage forms of vitamin C (including sustained release products) is that their rate of absorption is limited by the capacity of transport molecules in the intestinal wall (SVCT1, SVCT2); unabsorbed vitamin C is excreted from the body in feces. A suitable dosage form to accommodate the 
increased demand for vitamin C (e.g., in connection with increased stress or sensitivity to allergies or infectious disease) is one based on liposomal absorption. Unlike conventional absorption in the intestine, liposomal absorption provides for higher bioavailability of vitamin C. With this dosage form, vitamin $\mathrm{C}$ gets absorbed via Peyer's patches and enterocytes to be further transported by the lymphatic system. The substantially higher absorption rates of vitamin $\mathrm{C}$ result in its higher bioavailability to all body systems, such as the immune and nerve cells which depend on high intracellular levels for their proper functioning. The advantages of liposomal dosage forms include accelerated and higher rates absorption from the intestine, enhanced stability, protection of the intestine against potentially irritating agents and increased bioavailability of the active substance. These benefits have been documented in clinical and pharmacokinetic studies [28-31]. Comparisons of the plasma levels of ascorbic acid after the administration of a single $1 \mathrm{~g}$ dose of the various vitamin $\mathrm{C}$ dosage forms (see Figure 1 ) clearly indicate the benefits of RosaCelip-LD ${ }^{\circledR}$ (InPharm Clinic, Jesenice u Prahy, Czech Republic) with liposomal delivery. (RosaCelip-LD ${ }^{\circledR}$ formulation contains vitamin $\mathrm{C}$ with rosehip extract and citrus bioflavonoids) RosaCelip- $L D^{\circledR}$ has a superior effect on plasma vitamin $C$ levels compared to other dosage forms; these higher levels persist for a period of 12 hours, thus ensuring longer bioavailability of the active substance.

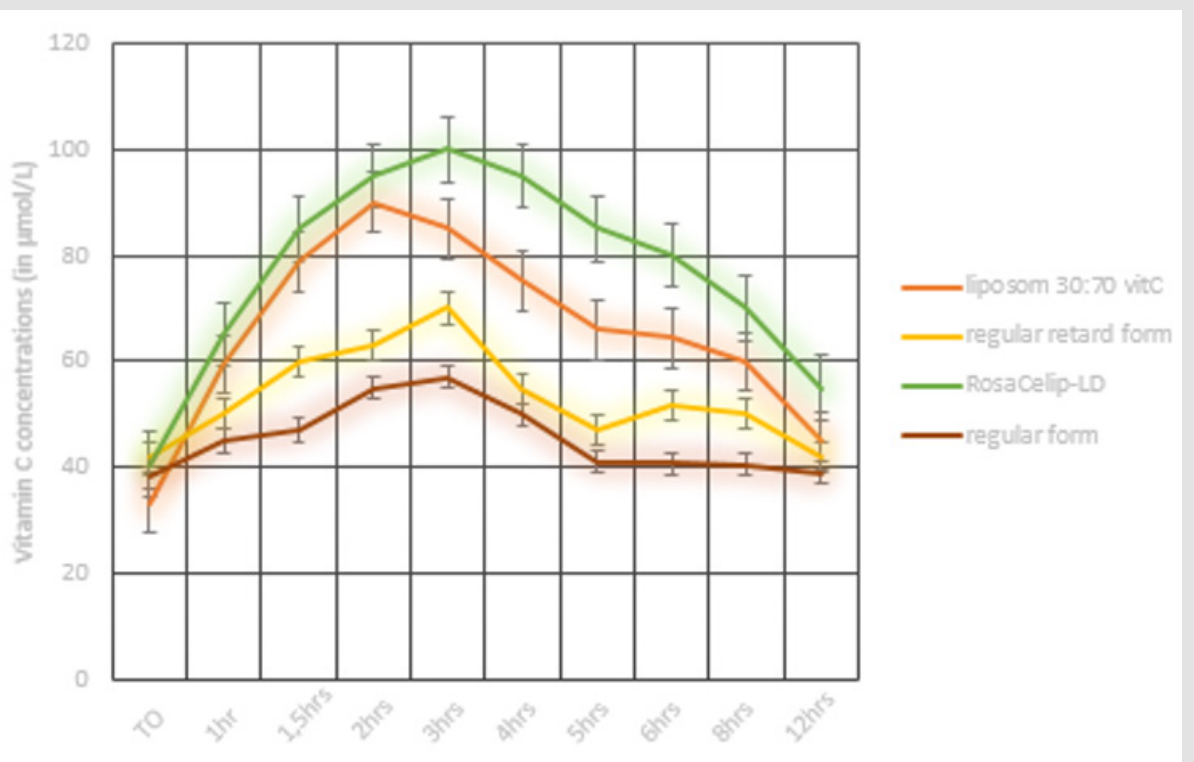

Figure 1: Plasma concentrations of ascorbic acid after a single oral dose of $1 \mathrm{~g}$ of vitamin $\mathrm{C}$ in various dosage forms (regular form $=$ non-proprietary vitamin $C$ dosage form, regular retard form $=$ retard vitamin $C$ form, liposome 30: 70 vitC $=$ liposomal vitamin C dosage form containing 30\% of phosphatidylcholine and $70 \%$ of vitamin C, RosaCelip-LD $\AA=$ vitamin $C$ with liposomal delivery in combination with a rosehip extract and citrus bioflavonoids.

\section{SCREENING FOR VITAMIN C SATURATION IN CHILDREN}

\section{Vitamin C saturation in children living in the Ostrava region}

\section{Patients and Methodology}

In 2019, a group of 150 children underwent preliminary assessment of urinary vitamin C levels in the Department of Pediatrics of Agel Hospital in Ostrava-Vítkovice. The group included 54\% females and 46\% males aged less than 18 years. The overwhelming majority of patients were those with acute respiratory tract infections (pharyngitis, laryngitis, bronchitis, bronchopneumonia) followed by (in terms of frequency) children with inflammatory bowel disease (mostly acute gastroenteritis) and kidney disease (acute pyelonephritis). Vitamin C levels were determined using test strips to assess ascorbic acid levels in the urine (Uro C Kontrol, InPharm, Czech Republic). The technique used by the manufacturer is based on the reaction of a chelating agent with a polyvalent metal ion to form a chelate complex and use of a test strip, with the results read by matching any color change in the strip with the color shown on a provided color chart (30 seconds after dipping in a fresh urine sample). Yellow color indicates a normal value (100 mg/dL and greater), whereas decreased levels are indicated by various shades of green to blue-to-green color (50, 20,10 , and $1 \mathrm{mg} / \mathrm{dL}$ ). The measured concentration of vitamin $\mathrm{C}$ in the urine provides preliminary information about any potential ascorbic acid deficiency and its severity. According to the protocol, test strips were evaluated by a physician.

\section{Results}

The preliminary assessment of vitamin C levels in the urine identified $23 \%$ with the most severe deficiency of vitamin $\mathrm{C}$ in the urine $(1 \mathrm{mg} / \mathrm{dL}), 41 \%$ with a deficiency at the level of $10 \mathrm{mg} / \mathrm{dL}$; $11 \%$ with a deficiency at the level of $20 \mathrm{mg} / \mathrm{dL}$; and $14 \%$ with a deficiency at the level of $50 \mathrm{mg} / \mathrm{dL}$. Full saturation $(100 \mathrm{mg} / \mathrm{dL})$ 
was achieved by only $11 \%$. The data suggest marked vitamin C deficiency in $75 \%$ of children with only $25 \%$ of children showing relatively sufficient saturation (the percentage values are rounded up to the nearest hundred). The process of data collection included recording of current pharmacotherapy, with the most frequently used classes of drugs being inhaled corticoids and antihistamines. Nearly $41 \%$ of children were admitted to hospital without any drug therapy. The remaining 59\% of children were on pharmacotherapy on admission and during hospitalization. In this subgroup of patients, $18 \%$ were diagnosed with severe vitamin $\mathrm{C}$ deficiency at the level of $1 \mathrm{mg} / \mathrm{dL} ; 43 \%$ at the level of $10 \mathrm{mg} / \mathrm{dL} ; 9 \%$ at the level of $20 \mathrm{mg} / \mathrm{dL}$; and $16 \%$ at the level of $50 \mathrm{mg} / \mathrm{dL}$. Only $14 \%$ had normal tissue vitamin C saturation. Probiotics or vitamin D were taken by a small proportion of children on admission $(2.6 \%$ and $5.3 \%$, respectively). No correlation was found between treatment with probiotics and vitamin $\mathrm{C}$ levels in the urine. Children using vitamin D were invariably on concomitant drug therapy. There was only 1 child with normal vitamin C saturation (100 mg/dL) while taking vitamin D (Vigantol) in combination with cough suppressants; the level of tissue saturation with vitamin $C$ in the other 5 children taking vitamin D was only 1 to $10 \mathrm{mg} / \mathrm{dL}$.

The study group was also evaluated by age categories (preschool children and schoolchildren). Pre-school children up to 6 years of age made up $67 \%$ of those hospitalized. In this subgroup,
14 patients were found to have full vitamin C saturation $(100 \mathrm{mg} /$ $\mathrm{dL}$, a high proportion given the fact that, in the whole study group of both pre-school children and schoolchildren), full vitamin $\mathrm{C}$ saturation was documented in only 16 children. Normal values were identified in only 2 children ages 6 years and above. Another parameter assessed was the relation between obesity and vitamin C saturation. Obese children were identified in the age category of $8-14$ years, making up $5.3 \%$ of the entire subgroup ( 4 boys and girls each). None of the obese children achieved full vitamin C saturation $(100 \mathrm{mg} / \mathrm{dL})$; vitamin C levels in the urine of $1 \mathrm{mg} /$ $\mathrm{dL}, 10 \mathrm{mg} / \mathrm{dL}, 20 \mathrm{mg} / \mathrm{dL}$ and $50 \mathrm{mg} / \mathrm{dL}$ were determined in 2 , 2, 1 and 3 children, respectively. In the subgroup with full tissue vitamin C saturation (100 mg/dL), 50\% used supplementation with probiotics or vitamin $\mathrm{D}$, either alone, or in combination with other drugs. In this subgroup, only one child used no medication or dietary supplements, and one child was treated with antiepileptic agents.

The most severe deficiency ( $1 \mathrm{mg} / \mathrm{dL}$ ) was diagnosed in 34 children, of which half were below 6 years of age. On admission to hospital, these patients were more likely to use antibiotics, or had no medication use at all. Results of assessment of vitamin $\mathrm{C}$ levels in the urine using the Uro C Kontrol test strips in children enrolled in the above subgroups are shown in Table 1.

Table 1: Results of assessment of vitamin C levels in urine 150 children admitted to the Department of Pediatrics of Agel Hospital in Ostrava-Vítkovice.

\begin{tabular}{|c|c|c|c|c|c|c|c|c|c|c|}
\hline \multicolumn{11}{|c|}{ Pediatric Department, AGEL Hospital, Ostrava-Vítkovice (2019) } \\
\hline $1 \mathrm{mg} / \mathrm{mL}$ & 34 & $23 \%$ & 06 & 600 & \multirow{3}{*}{112} & \multirow{3}{*}{$75 \%$} & \multirow{4}{*}{134} & \multirow{4}{*}{$89 \%$} & \multirow{5}{*}{150} & \multirow{5}{*}{$100 \%$} \\
\hline $10 \mathrm{mg} / \mathrm{mL}$ & 62 & $41 \%$ & 0 & 077 & & & & & & \\
\hline $20 \mathrm{mg} / \mathrm{mL}$ & 16 & $11 \%$ & & & & & & & & \\
\hline $50 \mathrm{mg} / \mathrm{mL}$ & 22 & $14 \%$ & & & & & & & & \\
\hline $100 \mathrm{mg} / \mathrm{mL}$ & 16 & $11 \%$ & & & & & & & & \\
\hline
\end{tabular}

\section{Discussion}

Overall, the above data emerging from the survey can be interpreted as follows: about three in four children hospitalized in the Department of Pediatrics (mainly for inflammatory conditions involving the respiratory or gastrointestinal tract, or the kidney) have vitamin $\mathrm{C}$ deficiency. More than half had measurements consistent with pre-scurvy to scurvy. Only one in four children achieved satisfactory vitamin $\mathrm{C}$ levels, and only one in ten children have physiological vitamin C levels. A physiological level of vitamin C saturation $(100 \mathrm{mg} / \mathrm{dL})$ was determined in $88 \%$ of children aged up to 6 years; and only $12 \%$ of children aged 6 years and over have normal values of vitamin $\mathrm{C}$ saturation. In regard to the relationship between an individual's level of vitamin $\mathrm{C}$ in the urine and instituted therapy (a variable not included in Table 1), our preliminary data indicate that, in the subgroup with physiological vitamin $\mathrm{C}$ levels (100 mg/dL), 25\% of children were on concomitant therapy with vitamin $\mathrm{D}$, and $38 \%$ of children used probiotics, with only $6 \%$ of children being on permanent pharmacotherapy. Interestingly, our data showed that obese children did not achieve physiological saturation $(100 \mathrm{mg} / \mathrm{dL})$ in a single case.

\section{Vitamin C saturation in children living in the Olomouc region: preliminary results}

A similar survey designed to assess urinary vitamin C levels was undertaken in the Department of Pediatrics of Olomouc University Hospital. While the data are preliminary, we deem it appropriate to present them briefly just for comparison. The survey enrolled a total of 280 children (200 boys, 80 girls), of which 236 were examined in a clinic of allergology and 44 in a clinic of nephrology. Among pediatric patients with an allergy, the urinary test identified $10 \%$ of children with the most severe vitamin C deficiency $(1 \mathrm{mg} / \mathrm{dL}) ; 30 \%$ with a deficiency at the level of $10 \mathrm{mg} / \mathrm{dL} ; 35 \%$ with a deficiency at the level of $20 \mathrm{mg} / \mathrm{dL}$; and $23 \%$ with a deficiency at the level of 50 
$\mathrm{mg} / \mathrm{dL}$. Full vitamin C saturation (100 mg/dL) was observed in only $2 \%$ of patients. It follows from the above that a vitamin $\mathrm{C}$ deficiency was present in $98 \%$ of children (the percentage values are rounded up to the nearest hundred). Among patients with a kidney disease, the most severe vitamin C deficiency ( $1 \mathrm{mg} / \mathrm{dl}$ ) was found in $36 \%$, with deficiency levels of $10 \mathrm{mg} / \mathrm{dL}, 20 \mathrm{mg} / \mathrm{dL}$, and $50 \mathrm{mg} /$

Table 2: Results of assessment of vitamin C levels in the urine in 236 children attending the Clinic of Allergology, Department of Pediatrics of Olomouc University Hospital.

\begin{tabular}{|c|c|c|c|c|c|c|c|c|c|c|}
\hline \multicolumn{11}{|c|}{ Pediatric Department, Olomouc University Hospital (2019) } \\
\hline \multicolumn{11}{|c|}{ Clinic of Allergology } \\
\hline $1 \mathrm{mg} / \mathrm{mL}$ & 24 & $10 \%$ & 06 & 1000 & \multirow{3}{*}{178} & \multirow{3}{*}{$75 \%$} & \multirow{4}{*}{232} & \multirow{4}{*}{$98 \%$} & \multirow{5}{*}{236} & \multirow{5}{*}{$100 \%$} \\
\hline $10 \mathrm{mg} / \mathrm{mL}$ & 72 & $30 \%$ & 00 & $40 \%$ & & & & & & \\
\hline $20 \mathrm{mg} / \mathrm{mL}$ & 82 & $35 \%$ & & & & & & & & \\
\hline $50 \mathrm{mg} / \mathrm{mL}$ & 54 & $23 \%$ & & & & & & & & \\
\hline $100 \mathrm{mg} / \mathrm{mL}$ & 4 & $2 \%$ & & & & & & & & \\
\hline
\end{tabular}

Table 3: Results of assessment of vitamin C levels in the urine in 44 children attending the Clinic of Nephrology, Department of Pediatrics of Olomouc University Hospital.

\begin{tabular}{|c|c|c|c|c|c|c|c|c|c|c|}
\hline \multicolumn{11}{|c|}{ Pediatric Department, Olomouc University Hospital (2019) } \\
\hline \multicolumn{11}{|c|}{ Clinic of Nephrology } \\
\hline $1 \mathrm{mg} / \mathrm{mL}$ & 16 & $36 \%$ & 24 & 770 & \multirow{3}{*}{42} & \multirow{3}{*}{$95 \%$} & \multirow{4}{*}{44} & \multirow{4}{*}{$100 \%$} & \multirow{5}{*}{44} & \multirow{5}{*}{$100 \%$} \\
\hline $10 \mathrm{mg} / \mathrm{mL}$ & 18 & $41 \%$ & 37 & 1170 & & & & & & \\
\hline $20 \mathrm{mg} / \mathrm{mL}$ & 8 & $18 \%$ & & & & & & & & \\
\hline $50 \mathrm{mg} / \mathrm{mL}$ & 2 & $5 \%$ & & & & & & & & \\
\hline $100 \mathrm{mg} / \mathrm{mL}$ & 0 & $0 \%$ & & & & & & & & \\
\hline
\end{tabular}

Table 4: Results of assessment of vitamin C levels in urine 280 children attending the Clinics of Allergology and Nephrology (combined), Department of Pediatrics of Olomouc University Hospital.

\begin{tabular}{|c|c|c|c|c|c|c|c|c|c|c|}
\hline \multicolumn{11}{|c|}{ Pediatric Department, Olomouc University Hospital (2019) } \\
\hline \multicolumn{11}{|c|}{ Clinics of Allergology and Nephrology Combined } \\
\hline $1 \mathrm{mg} / \mathrm{mL}$ & 40 & $15 \%$ & 130 & $470 \%$ & \multirow{3}{*}{220} & \multirow{3}{*}{$79 \%$} & \multirow{4}{*}{276} & \multirow{4}{*}{$99 \%$} & \multirow{5}{*}{280} & \multirow{5}{*}{$100 \%$} \\
\hline $10 \mathrm{mg} / \mathrm{mL}$ & 90 & $32 \%$ & 130 & $47 \%$ & & & & & & \\
\hline $20 \mathrm{mg} / \mathrm{mL}$ & 90 & $32 \%$ & & & & & & & & \\
\hline $50 \mathrm{mg} / \mathrm{mL}$ & 56 & $20 \%$ & & & & & & & & \\
\hline $100 \mathrm{mg} / \mathrm{mL}$ & 4 & $1 \%$ & & & & & & & & \\
\hline
\end{tabular}

Our survey indicates that the overwhelming majority of children assessed in the Department of Pediatrics of Olomouc University Hospital (similar to those admitted to the hospital in Ostrava-Vítkovice) showed decreased vitamin C levels. In the subgroup of children with allergies, normal vitamin $C$ levels were detected only exceptionally whereas no child attending the clinic of nephrology had normal levels; all patients exhibited decreased vitamin $\mathrm{C}$ levels. In fact, data obtained from children living in the Olomouc region were even more alarming than those obtained in the hospital in Ostrava-Vítkovice and are indicative of absolutely inadequate vitamin $\mathrm{C}$ intakes.

\section{CONCLUSION}

Vitamin $\mathrm{C}$ is a substance indispensable for the human body. It is absolutely necessary for a healthy ontogenetic development and
dL determined in $41 \%, 18 \%$, and $5 \%$ of the children respectively. Full tissue vitamin C saturation (100 mg/dL) was not achieved by a single child in this particular subgroup. Results of the survey using Uro C Kontrol test strips in children assessed in the Department of Pediatrics of Olomouc University Hospital are shown in Tables 2-4. 
levels in the urine using test strips, a technique recently employed in 150 children living in the Ostrava region and 280 children living in the Olomouc region.

Overall, our survey revealed a marked prevalence of children with decreased vitamin $\mathrm{C}$ saturation, a condition which increases the risk of improper functioning or a disorder involving the immune, nervous or other systems, which may potentially result in reduced resistance to stress, increased susceptibility to respiratory tract infections and, generally, inflammatory conditions associated with oxidative stress. Hence, it is imperative to provide adequate vitamin $\mathrm{C}$ supplementation in children with decreased vitamin $\mathrm{C}$ saturation to ensure the proper functioning of all body systems. The best source of vitamin $\mathrm{C}$ continues to be a varied diet, rich in vegetables and fruits; however, as shown by our study, dietary vitamin $\mathrm{C}$ intake, in a big proportion of our pediatric population remains fairly inadequate and below the recommended values.

\section{References}

1. U.S. Department of Health and Human Services, National Institutes of Health, Ofiice of Dietary Supplements (2021) Vitamin C: Fact Sheet for Health Professionals. Retrieved from: https://ods.od.nih.gov/ factsheets/VitaminC-HealthProfessional/.

2. Carr AC, Maggini S (2017) Vitamin C and immune function. Nutrients 9(11): 1211

3. Bakaev VV, Duntau AP (2004) Ascorbic acid in blood serum of patients with pulmonary tuberculosis and pneumonia. Int J Tuberc Lung Dis 8(2): 263-266

4. Hunt C, Chakravorty NK, Annan G, Habibzadeh N, Schorah CJ, et al. (1994) The clinical effects of vitamin C supplementation in elderly hospitalised patients with acute respiratory infections. Int J Vitam Nutr Res 64(3): 212-219.

5. Uesato S, Kitagawa Y, Kaijima T, Tokuda H, Okuda M, et al. (2001) Inhibitory effects of 6-0-acylated L-ascorbic acids possessing a straightor branched-acyl chain on Epstein-Barr virus activation. Cancer Lett 166(2): 143-146.

6. Cinatl J, Cinatl J, Weber B, Gümbel HO, Chenot JF, et al. (1995) In vitro inhibition of human cytomegalovirus replication in human foreskin fibroblasts and endothelial cells by ascorbic acid 2-phosphate. Antiviral Res 27(4): 405-418.

7. Leibovitz B, Siegel BV (1981) Ascorbic acid and the immune response Adv Exp Med Biol 135: 1-25.

8. Dey S, Bishayi B (2018) Killing of S.aureus in murine peritoneal macrophages by ascorbic acid along with antibiotics chloramphenicol or ofloxacin: correlation with inflammation. Microb Pathog 115: 239-250.

9. Kim Y, Kim H, Bae S, Choi J, Lim SY, et al. (2013) Vitamin C is an essentia factor on the anti-viral immune response through the production of interferon-alpha/beta at the initial stage of influenza A virus $\left(\mathrm{H}_{3} \mathrm{~N}_{2}\right)$ infection. Immune Netw 13(2): 70-74.

10. Li W, Maeda N, Beck MA (2006) Vitamin C deficiency increases the lung pathology of influenza virus-infected gulo-/- mice. J Nutr 136(10): 2611 2616.

11. Cai Y, Li YF, Tang LP, Tsoi B, Chen M, et al. (2015) A new mechanism of vitamin $\mathrm{C}$ effects on $\mathrm{A} / \mathrm{FM} / 1 / 47(\mathrm{H} 1 \mathrm{~N} 1)$ virus-induced pneumonia in restraint-stressed mice. Biomed Res Int 675149. 12. Kataoka A, Imai H, Inayoshi S, T Tsuda (1993) Intermittent high-dose vitamin C therapy in patients with HTLV-I associated myelopathy. J Neurol Neurosurg Psy 56(11): 1213-1216.
12. Kataoka A, Imai H, Inayoshi S, T Tsuda (1993) Intermittent high-dose vitamin $\mathrm{C}$ therapy in patients with HTLV-I associated myelopathy. J Neurol Neurosurg Psy 56(11): 1213-1216.

13. Harakeh S (1997) NF-kappa B-independent suppression of HIV expression by ascorbic acid. AIDS Res Hum Retroviruses 13(3): 235-239.

14. Hosakote YM, Jantzi PD, Esham DL, Spratt H, Kurosky A, et al. (2011) Viral-mediated inhibition of antioxidant enzymes contributes to the pathogenesis of severe respiratory syncytial virus bronchiolitis. Am J Respir Crit Care Med 183(11): 1550-1560.

15. Cahill L, Corey PN, El Sohemy A (2009) Vitamin C deficiency in a population of young Canadian adults. Am J Epidemiol 170(4): 464-471.

16. Kiondo P, Tumwesigye NM, Wandabwa J (2012) Plasma vitamin C assay in women of reproductive age in Kampala, Uganda, using a colorimetric method. Trop Med Int Health 17: 191-196.

17.Vinas BR, Barba LR, Ngo J, Gurinovic M, Novakovic R, et al. (2011) Projected prevalence of inadequate nutrient intakes in Europe. Ann Nutr Metab 59(2-4): 84-95.

18. Wrieden WL, Hannah MK, Bolton-Smith C, Tavendale R, Morrison C, et al. (2000) Plasma vitamin $C$ and food choice in the third Glasgow MONICA population survey. J Epidemiol Community Health 54(5): 355-360.

19. Hagel AF, Albrecht H, Dauth W, Hage Wl, Vitali F, et al. (2018) Plasma concentrations of ascorbic acid in a cross section of the German population. J Int Med Res 46(1): 168-174.

20. Barrita JLS, Santiago Sánchez M (2012) Antioxidant role of ascorbic acid and his protective effects on chronic diseases. In: MoralesGonzales JA (ed.). Oxidative stress and chronic degenerative diseases: a role for antioxidants. Retrieved from: https://www.intechopen. com/ books/oxidative-stress-and-chronic-degenerative-diseasesa-role-forantioxidants/antioxidant-role-of-ascorbic-acid-and-hisprotectiveeffects-on-chronic-diseases.

21. Villalpando S, Montalvo-Velarde I, Rivera JA, Zambrano N, García-Guerra A, et al. (2003) Vitamins A, and C and folate status in Mexican children under 12 years and women 12-49 years: A probabilistic national survey. Salud Publ Mex 4-5: S508-S519.

22. Sivakumar B, Nair KM, Sreeramulu D (2020) Effect of micronutrient supplement on health and nutritional status of schoolchildren: biochemical status. Nutrients 12(1): S1-7.

23. Kothari P, Tate A, Adewumi A, Kinlin LM, Ritwik P, et al. (2020) The risk for scurvy in children with neurodevelopmental disorders. Spec Care Dentist 40: 1-9.

24. Ceglie G, Macchiarulo G, Marchili MR, Marchesi A, Rotondi Aufiero L, et al. (2019) Scurvy: still a threat in the well-fed first world? Arch Dis Child 104(4): 381-383

25. Rowe C, Carr AC (2020) Global vitamin C status and prevalence of deficiency: a cause for concern? Nutrients 12(7): 2008.

26. Carr AC, Rowe C (2020) Factors affecting vitamin C status and prevalence of deficiency: a global health perspective. Nutrients 12: 1963.

27. Jackson JA, Wong K, Krier C (2005) Screening for vitamin C in the urine: is it clinically significant? J Orthomol Med 20: 259-261.

28. Gopi S, Balakrishnan P (2020) Evaluation and clinical comparison studies on liposomal and non-liposomal ascorbic acid (Vitamin C) and their enhanced bioavailability. J Liposome Res 6: 1-9.

29. Lukawski M, Dalek P, Borowik T, Foryś A, Langner M, et al. (2020) New oral liposomal vitamin $\mathrm{C}$ formulation: properties and bioavailability. J Liposome Res 30(3): 227-234.

30. Padayatty J, Sun H, Wang Y, Riordan HD, Hewitt SM, et al. (2004) Vitamin C pharmacokinetics: implications for oral and intravenous use. Ann Intern Med 140 (7): 533-537

31. Hickey S (2008) Pharmacokinetics of oral vitamin C. Journal of Nutrition and Environmental Medicine 17(3): 169-177. 
ISSN: 2574-1241

DOI: 10.26717/BJSTR.2021.35.005679

Lucie Kotlářová. Biomed J Sci \& Tech Res

(c) (P) This work is licensed under Creative BY Commons Attribution 4.0 License

Submission Link: https://biomedres.us/submit-manuscript.php

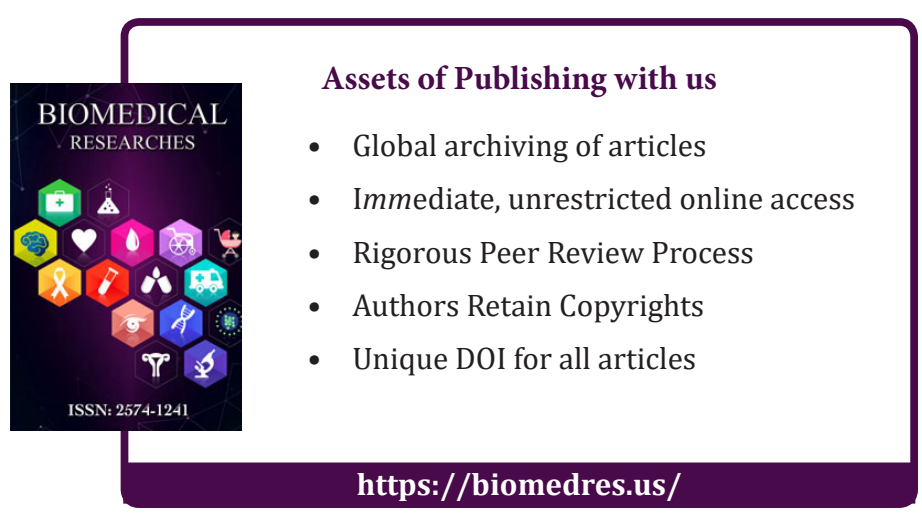

